\title{
MENGATASI GANGGUAN PROSES SAMPAINYA PESAN MELALUI MOTIVASI KESADARAN PADA PECANDU NARKOBA
}

\author{
DOI: https://doi.org/10.38214/jurnaldawahstidnatsir.v4i01.94 \\ Ahmad Misbahul Anam \\ tabahkan@gmail.com \\ STID Muhammad Natsir - Indonesia
}

\begin{abstract}
Dalam banyak kasus negara maju dan negara berkembang, narkoba masih menjadi bagian dari sistem ekonomi dunia. Antara kepentingan devisa cukai pajak sebagai pemasukan negara dan bagaimana mengatasi para pecandunya, yang merusak kehidupan pecandu dan sistem sosial. Kerusakan tersebut menyebabkan rusaknya sistem penangkap pesan, sebagai media untuk perbaikan diri. Agama memiliki kesempatan untuk mengembalikan sistem komunikasi ini, agar tidak berubah menjadi pengganggu (noise) bagi proses perbaikan. Penelitian ini mengenalkan pendekatan komunikasi yang dipaparkan oleh Shannon dan Waber, dimana dalam komunikasi selalu ada noise (hambatan) dalam prosesnya. Pecandu narkoba dijadikan obyek kajian, karena memiliki potensi gangguan tersebut. Didekatkan penanganannya melalui sentuhan alQur'an dan sunnah sebagai keperluan fitrah bagi perbaikan jiwa yang sedang mengalami gangguan. Penelitian ini membetasi diri hanya meneliti atas data-data yang telah dilakukan oleh para peneliti sebelumnya, karena kondisi Covid-19 yang masih membatasi pertemuan dengan korban narkoba.
\end{abstract}

Key words: pesan, gangguan, narkoba 


\section{PENDAHULUAN}

Masalah yang masih terus menjadi diskusi banyak pakar dan pemerintah adalah ledakan jumlah penduduk dan penganngguran. Tapi apakah hanya itu saja masalahnya? Tentu tidak! Masih banyak lagi masalah ikutan yang sebenarnya lebih mengerikan bagi kehidupan bersama. Diantara masalah itu adalah soal penanganan minuman keras, sek bebas, bunuh diri dan moral. Penanganan masalah ini tidak mudah, memerlukan peran seluruh komponen. Keluarga, lembaga pendidikan, negara dan juga tokoh agama, harus menyatukan langkah untuk ikut serta dalam proyek penanganannya. Miras dalam skala yang lebih luas, telah berubah menjadi sumber pendapatan baru. Baik sebagai sumber ekonomi bagi warga, atau menjadi sumber penghasilan negara berupa cukai pajak.

Sementara pemerintah malah membuka investasi bagi industri minuman beralkohol atau minuman keras (miras) di sejumlah daerah melalui Peraturan Presiden (Perpres) Nomor 10 Tahun 2021. Pelonggaran investasi miras ini dinilai akan berdampak pada tanggapan asing terhadap Indonesia. Terutama bagi negara muslim yang memiliki potensi untuk investasi di Indonesia. Menurut peneliti Indef, Bhima Yudistira, Dibukanya investasi pada sektor miras juga menjadi pertanyaan untuk menggenjot pendapatan negara. Pasalnya pendapatan besar dari produk minuman alkohol berasal dari penerapan cukai. Dibukanya investasi miras juga akan meningkatkan konsumsi dalam negeri. Pasalnya industri yang berinvestasi akan mengejar pasar dalam negeri sebelum ekspor. Bhima meminta agar beleid tersebut kembali dipertimbangkan oleh pemerintah. Bukan hanya moral, Bhima juga menyampaikan terdapat kerugian ekonomi dari sisi kesehatan ${ }^{1}$.

Miras, sek bebas dan bunuh diri berjalan beriringan. Sebab miras berakibat pada hilangnya sistem rasa malu dan munculnya sifat nekat tanpa hitungan. Halusinasi menguasai pikiran dan sarat penggerak kesadaran. Inginnya selalu senang, bebas dan merasa hebat. Pecandunya selalu tak bisa mengendalikan emosi dan akalnya. Sek bebas menjadi pilihan menyalurkan dorongan nafsu birahi para pecandu, sebagai puncak kesenangan. Sementara yang lainya, minuman keras adalah cara paling simple bagaimana bunuh diri

\footnotetext{
${ }^{1}$ Kontan.co.id, Senin, 01 Maret 2021 / 20:12 WIB
} 
tidak dirasa. Artinya, minuman keras digunakan para pecandu dan pribadi yang sedang mendapat tekanan kejiwaan sebagai media yang diharapkan mampu memberikan rasa tenang saat menyelesaikan suatu aktivitas, atau menghilangkan rasa takut saat memutuskan untuk bunuh diri.

Kebijakan minuman keras seperti tidak memiliki legetimisi yang kuat. Antara produksi, pasokan, penjualan dan bagaimana konsumer selalu bermain "kucing-kucingan lewat jalur tikus". Tiada pesta tanpa minuman keras, dimanamana barang ini mudah ditemukan. Menurut jurnal The Lancet menemukan peningkatan konsumsi minuman beralkohol di selruuh dunia hingga 70 persen. Para penulis memperingatkan bahwa aktivitas ini bisa berbahaya untuk masyarakat dan para pembuat kebijakan harus segera mengatasinya. Peningkatan yang tinggi ini bisa dibandingkan pada 30 tahun yang lalu dengan hitungan produksi antar tahun 1990 dengan jumlah konsumsi 20.999 juta liter pertahun dan meningkat pada tahun 2017 menjadi 35.676 juta liter pertahun. Peningkatan terjadi justru di negara-negara miskin dan berkembang ${ }^{2}$.

Menurut laporan WHO bunuh diri terjadi setiap detik di seluruh dunia, bahkan jauh lebih banyak dibandingkan orang mati akibat perang. Total terdapat ada 800 ribu orang bunuh diri setiap tahun. Dalam laporanya WHO mengatakan, "Bunuh diri adalah masalah kesehatan masyarakat global. Kematian ini menjadi penyebab utama kedua kematian dikalangan pemuda yang berusia antara 15 sampai 19 tahun dan pembunuh kedua setelah saat kelahiran. Pada remaja lelaki, bunuh diri menempati posisi ketiga di belakang luka di jalanan dan kekerasan antar manusia ${ }^{3}$. Amerika berada pada posisi teratas penggunaa narkoba pada remaja, bahkan 10 kali lebih besar dibanding Jepang. Anak SD kelas 6 pada tahun 1975 naik 3 kali lipat pengguna narkobanya. Tahun 1989 dalam poling yang dilakukan Gallup, enan dari 10 remaja menempatkan narkoba sebagai masalah terbesar dalam generai mereka ${ }^{4}$.

Menurut Kristiana Siste, dari Departemen Ilmu Kesehatan Jiwa Fakultas Kedokteran Universitas Indonesia (FKUI), "alkohol menjadi penyumbang seseorang dirawat di rumah sakit dengan gangguan jiwa atau mental. Jadi banyak sekali komorbiditas antara penggunaan alkohol dengan gangguan jiwa lainnya misalnya psikotik. Kecanduan alkohol juga sering kali

\footnotetext{
2 https://m.liputan6.com, 10 mei 2019, 21.00 wib

${ }^{3}$ https:// cnnindonesia.com, selasa 10/09/2019 pada jam 05:40

4 Thomas Lickona, Educating for Character, Bumi Aksara, 2016, Jakarta, hlm. 528-529
} 
bersamaan dengan kecanduan perilaku seperti kecanduan judi dan kecanduan internet. Penggunaan alkohol bisa berhubungan dengan keinginan untuk bunuh diri. Dikatakan hampir 1,9 kali muncul ide bunuh diri atau 3 kali sudah melakukan percobaan bunuh diri dan 2,59 kali percobaan bunuh diri berhasil. Penggunaan alkohol memang erat dengan ide mengakhiri hidup karena ada gangguan depresi yang dialami oleh orang yang kecanduan alkohol ${ }^{5}$.

Di Indonesia grafik seks bebas menggambarkan bahwa sekitar 62,7\% remajanya telah melakukan hubungans seks bebas diluar nikah. Ada $20 \%$ dari 94.270 perempuan mengalami hamil di luar nikah pada usia remaja dan $21 \%$ diantaranya pernah melakukan aborsi. Selain itu dalam rentang wakty 3 bulan terdapat kasus HIV sebanyak 10.203 dan 30\% nya adalah penderita dari kalangan remaja. Catatan ini sebagaimana laporan hasil survei yang dilakukan oleh Komite Perlindungan Anak Indonesia (KPAI) dan Kementerian Kesehatan pada bulan Oktober $2013^{6}$. Alkohol memperngaruhi tahapan seks bebas, karena dipandang lebih berani, tahan lama, dan memiliki sensasi kenikmatan yang lebih?

Tidak hanya mengganggu kesehatan fisik, pecandu alkohol juga bisa mengalami gangguan kejiwaan. Pakar kesehatan jiwa, Danardi Sosrosumihardjo mengatakan, orang yang sudah kecanduan alkohol pola pikirnya akan terganggu. Tidak lagi takut bahaya, apalagi aturan. "Orang yang sudah kecanduan alkohol kesehatan jiwanya akan terganggu. Yang terburuknya bisa mengalami skizofrenia, atau kita menyebutnya psiko-organik," kata Danardi. Penanganan orang yang sudah kecanduan alkohol, kata dia, sebetulnya tidak berbeda dengan pecandu narkoba. Mereka perlu direhabilitasi agar bisa lepas dari keinginan untuk selalu mengonsumsi alkohol. "Untuk yang sudah kecanduan, yang harus diterapi terlebih dahulu adalah pola pikirnya. Mereka harus kembali disadarkan kalau alkohol itu bisa membuatnya sakit, bahkan sampai meninggal. Kalau pola pikirnya sudah berhasil diluruskan, pengobatannya akan lebih mudah," jelas Danardi. ${ }^{8}$

Terhadap minuman keras, agama telah juga memberikan guidance yang jelas bagaimana menyikapinya. Bahkan juga dijelaskan manfaatnya bagi

\footnotetext{
${ }^{5}$ https://www.liputan6.com/disabilitas/read/4523607/picu-gangguan-mental-alkoholdisebut-sebagai-akar-kecanduan-judi-dan-bunuh-diri

${ }^{6}$ http://kompasiana.com, 17 Juni 2015

${ }^{7}$ http://ejournal3.undip.ac.id/index.php/jkm

${ }^{8}$ Berita Satu, Kamis, 11 Desember 2014 | 20:07 WIB
} 
kehidupan, serta akibat yang ditimbulkan pada resiko rusaknya kehidupan. Status minuman keras sendiri juga diberikan status hukumannya secara jelas, yaitu hukuman yang maksimal 'haram' berakibat pada besarnya dosa.

"Mereka bertanya kepadamu tentang khamr dan judi. Katakanlah, "Pada keduanya terdapat dosa yang besar dan beberapa manfaat bagi manusia, tetapi dosa keduanya lebih besar dari manfaatnya". Dan mereka bertanya kepadamu apa yang mereka nafkabkan. Katakanlah, "Yang lebi dari keperluan". Demikianlah Allah menerangkan ayat-ayatNya kepadamu supaya kamu berfikir'".

Minuman keras juga menjadi penghalang terlaksananya shalat. Sementara shalat adalah puncak ibadah, hubungan yang paling intim antara hamba dan pencipta berada dalam situasi ini. Karena minuman ini menyebabkan hilangnya kesadaran akal sebagai media mengingat niat, bacaan serta gerakan shalat. Status pemabuk seperti orang yang kehilangan akal, orang gila dan sedang tidur. Allah mengingatkan,

"Hai orang-orang yang beriman, janganlah kamu salat, sedang kamu dalam keadaan mabuk, sehingga kamu mengerti apa yang kamu ucapkan, (jangan pula hampiri masjid) sedang kamu dalam keadaan junub, terkecuali sekedar berlalu saja, bingga kamu mandi. Dan jika kamu sakit atau sedang dalam musafir atau datang dari tempat buang air atau kamu telah menyentuh perempuan, kemudian kamu tidak mendapat air, maka bertayamumlah kamu dengan tanah yang baik (suci), sapulah mukamu dan tanganmu. Sesunggubnya Allah Maha Pemaaf lagi Maha Pengampun" ${ }^{\prime 10}$.

Dalam perilaku sehari-hari, minuman keras akan mendekatkan diri pelaku pada perbuatan buruk yang disifatkan pada perilaku setan. Sementara manusia senantiasa didorong untuk berlindung dari setan, karena memang mereka telah bersumpah ingin menyesatkan manusia. Korban pertamanya ada dalam kehidupan Nabi Adam dan keluarganya dan berlanjut sampai kini.

"Hai orang-orang yang beriman, sesunggubnya (meminum) khamr, berjudi, (berkorban untuk) berhala, mengundi nasib dengan panah, adalab termasuk.

${ }^{9}$ QS. Al-Baqarah, 219

${ }^{10}$ QS. An-Nisa, 43 
perbuatan syaitan. Maka jaubilah perbuatan-perbuatan itu agar kamu mendapat keberuntungan" "1.

Melihat dampak dari miras yang tidak saja dipandang sebagai gaya hidup, ternyata dampak merusaknya jauh lebih besar dibandingkan manfaatnya. Kerusakan pada ekonomi pelaku dan keluarganya karena harta tersebut tidak memberikan nilai manfaat yang nyata, kecuali gaya hidup dan pemborosan. Demikina juga pada sisi kesehatan yang jela merusak, sebagaimana ayat diatas yakni merusak akal sebagai sumber informasi. Pada aspek hubungan sosial, sebagai manusia akan dapat menimbulkan komunikasi yang buruk. Para pemabuk pastilah tidak dapat mengontrol apa yang dikatakan, sehingga memudahkan konflik dalam komunikasi. Sementara rumah rehabilitasi sebagai media penanganannya masih minim dan belum banyak didirikan. Bentuk penangan bagi para pecandu baru sebetas dijerat hukum, itupuan pasal tuntutanya karena ulah perusakan yang dilakukan, serta sifat merugikan bagi orang lain.

Penelitian ini coba berusaha untuk mengungkap bagaimana kesadaran beragama dapat dimanfaatkan sebagai cara menangani para pecandu ataupun mengantisipasi calon korban barunya. Bagaimana sifat ataupun nilai yang ada, khususnya nilai yang tumbuh dari agama yang dianutnya dapat dijadikan stimulus bagi perbaikan dirinya. Hal ini menyangkut perbaikan kualitas jiwa sebagai perangkat potensi baik yang ada pada diri yang pecandu. Dalam kajian komunikasi simbolik, dimana manusia diposisikan lebih dari segalanya, -yaitu pada proses hubungan terkait komunikator, audien, media, dan konten- ternyata ada peristiwa yang dapat menghambat komunikasi, yang dalam pendekatan Shannon dan Weaver disebut dengan noise source (sumber gangguan).

Khususnya penelitian ini diharapkan mampu mengungkap bagaimana pesan dakwah (agama) berproses dalam komunikasi interaksional secara sosiologis, dengan menekankan pada situasi sosiologis kemanusiaan. Secara lebih kecil lagi, skup penelitian ini menitik beratkan pada bagaimana gangguan komunikasi diatasi, hal tersebut untuk coba mengungkap satu fenomena bahwa mengapa perubahan yang proses melalui jalur komunikasi sering mengalami kondisi yang tidak diinginkan, atau tidak sukses. Padahal dari sisi komunikator, pesan, saluran dan komuniken mengalami proses yang wajar. Ternyata ada gangguan yang menjadi penghambat proses komunikasi, pada aspek inilah

\footnotetext{
${ }^{11}$ QS. Al-Maidah, 90
} 
penelitian ini coba dilakukan. Penelitian ini berjudul, "MENGATASI GANGGUAN PROSES SAMPAINYA PESAN MELALUI MOTIVASI KESADARAN PADA PECANDU NARKOBA".

\section{HASIL DAN DISKUSI}

Menyebut minuman keras sebagai sumber masalah sosial adalah satu keniscayaan sosiologis karena nampak nyata dalam kehidupan. Bisa dirasakan dan bisa diungkap data-datanya, baik dari berita koran lokal, televisi, media virtual dan juga kejadian dilingkungan tepat tinggal. Korban yang paling menyedihkan adalah generasi muda, sebagian kecil orang tua dan para wanita. Jika melihat data, cukup besar penggemarnya. Demikian juga dengan dampak ikutanya, seperti bunuh diri dan seks bebas. Hal ini adalah ancaman nyata kehidupan, yang akan dapat merusah pribadi pelaku, keluarga, masyarakat dan juga akan dapat merobohkan ekosistem negara.

Kita bisa mengetengahkan hasil penelitian terkait hal tersebut dengan mengambil contoh pada kalangan remaja, pada kasus miras dan seks bebas. Menurut penelitian, awal mula seorang remaja terjerumus untuk melakukan seks bebas tidak mungkin langsung begitu saja terjadi. Pasti ada hal yang menyebabkan mereka ingin melakukan hal tersebut. Berikut adalah faktorfaktor yang menyebabkan remaja melakukan seks bebas : 1. Kekuatan iman yang memudar, 2. Kurangnya perhatian orang tua. 3. Rasa ingin tahu, 4. Tontonan tidak mendidik, 5. Rendahnya pengetahuan tentang bahaya seks bebas dan 6 . Salah bergaul ${ }^{12}$.

Menurut kajian Dadang Hawari ${ }^{13}$, pemakaian minuman keras dapat menimbulkan adiksi (addiction) yaitu ketagihan dan ketergantungan. Kemudian akan mengakibatkan gangguan mental organik (GMO), yaitu gangguan dalam fungsi berfikir, perasaan dan perilaku karena rusaknya sel otak. Gangguan mental oragnik pada diri seseorang dapat ditandai melalui gejala-gajala sebagai berikut.

\footnotetext{
12 https://www.balitbangham.go.id/detailpost/maraknya-budaya-seks-bebas-di-eraglobalisasi-suatu-refleksi-moral

${ }^{13}$ Dadang Hawari, Al-Quran Ilmu Kedokteran Jiwa dan Kesehatan Jiwa, Dana Bakti Primayasa, Yogyakarta, 1999, hlm. 161-162
} 
a) Terdapat dampak berupa perubahan perilaku, misalnya perkelahian dan tindak kekerasan lainnya, ketidak-mampuan menilai realitas (hilangnya daya nilai), gangguan dalam fungsi sosial dan pekerjaan.

b) Paling sedikit ada satu dari gejala fisiologik berikit ; pembicaraan cadel (slurred), gangguan kordinasi, cara jalan yang tidak mantap, nistakmus (mata jereng) dan muka nampak merah.

c) Paling sedikit ada satu dari gejala pikologik berikut ; perubahan perasaan (afek), mudah marah dan tersinggung (iritabilitas), banyak bicara (ngelantur), dan hendaya atau gangguan perhatian/konsentrasi. Hendaya ini besar pengaruhnya bagi kecelakaan lalu lintas.

Bagi mereka yang sudah ketagihan atau ketergantungan, bila pemakaiannya dihentikan akan menimbulkan sindrom putus alkohol. Gejala sindrom putus alkohol, khususnya yang dapat dilihat secara fisik ataupun dirasakan si pecandu adalah sebagai berikut,

a) Gemetaran (tremor) kasar pada tangan, lidah dan kelopak mata

b) Paling sedikit ada satu gejala berikut ; mual dan muntah, hiperaktivitas sarat autonom misalnya jantung berdebar-debar, berkeringat berlebihan dan tekanan darah meninggi, kecemasan (gelisah, tidak tenang, rasa ketakutan), perubahan alam perasaan menjadi pemuruh dan mudah tersinggung, stres dan muncul pikiran mau bunuh diri, hipotensi ortotastik (tekanan darah menurun karena perubahan posisi tubuh, berbaring, duduk dan berdiri), serta halusinasi dengar (mendengar suara-suara ancaman, padahal tidak ada suara ataupun sumber suara).

Jika memperhatikan pengaruh narkoba bagi para pecandu, dalam hubungan komunikasi nampak ada gangguan (noise) yang ditimbulkan. Gangguan tersebut berupa keterputusan pesan yang disampaikan, sehingga pesan tidak sampai. Tentu saat pesan tidak sampai, akan menghambat tujuan komunikasi yaitu berpindahnya informasi dari subyek ke obyek. Hal ini juga sejalan dengan kehidupan manusia itu sendiri yang memiliki maksud saling mengenal, dimana komunikasi adalah sarana perpindahan pesan tersebut.

Sebagaimana pula dalam kontek dakwah, suatu tradisi misi penyampai pesan yang sangat berpengaruh dalam sistem kemasyarakatan Islam, dimana komunikasi dakwah memiliki tujuan yang jelas, yaitu perubahan di masyarakat. 
Perubahan yang bersendi syariat, menuju nilai yang dipesan al-Qur'an dan Sunnah. Dakwah adalah komunikasi yang berdimensi ibadah, melaksanakan pesan Allah, menyampaikan pesan Allah sebagai way if life bagi hubungan manusia kepada Allah dan hubungan antar mereka sendiri. Efek perubahan tersebut sebagai puncak dan tujuan dari misi dakwah itu sendiri. Selain dakwah dapat dimaknai sebagai komunikasi yang khas sebagimana dalam tradisi komunikasi, karena tujuannya dalah perubahan maka didalamnya memerlukan sarana pelontar pesan dan penangkapnya yang seimbang. Sehingga antara yang diinginkan, dengan daya tangkap dari media dakwah tersebut memiliki kecocokan. Namun demikian, selalu hubungan komunikasi juga akan mengalami kondisi yang lain, hal tersebut boleh jadi adanya kerusakan sistem alat tangkap.

Kerusakan biasanya terjadi pada alat penangkap pesan, yaitu terganggunya sistem saraf penerima dan juga pengolah pesan. Alat tersebut menghambat hubungan komunikasi, dimana pesan tidak sampai atau mengalami kesulitan (terganggu) saat menuju audien. Artinya, selain ketersedian saran komunikasi yang ada, faktor gangguan memungkinkan terkendalanya pesan tersebut sampai pada yang dituju. -Teori Shannon dan weaver's membahas secara khusus aspek penghambat yang diistilahkan dengan noise.

\section{Model Shannon and Weaver's}

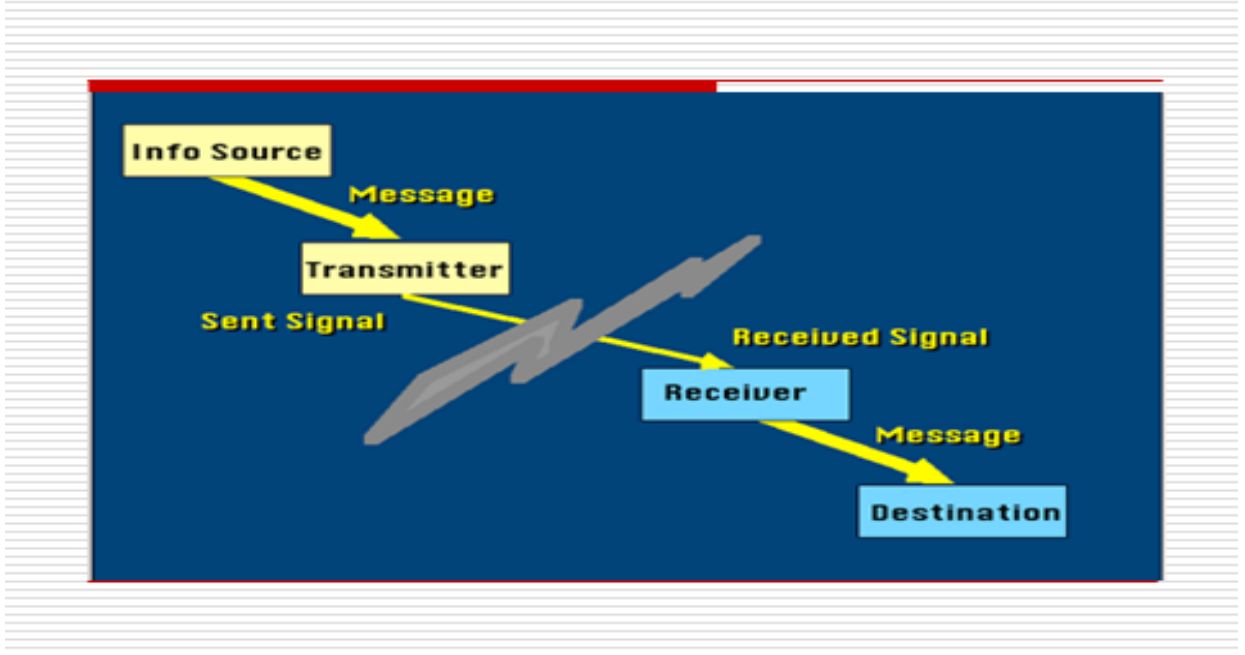

(Pendekatan Komunikasi Shannon dan Weaver) 
Dalam buku yang ditulis oleh Rosady Ruslan dengan judul Manajemen Publik Relation dan Media Komunikasi, beliau menjelaskan noise sebagai bagian dari unsur komunikasi terdiri dari 6 bagian. Pertama, sumber gangguan ( information source ; IS) adalah individu yang biasa disebut dengan komunikator. Kedua, pesan (mesage: M ) gagasan, ide, nilai yang akan disampaikan oleh komunikator kepada audiens dalam rangka pembinaan. Tiga, alat saluran penyampai (transmitter/ channel; $\mathrm{T}$ ) adalah sarana yang digunakan untuk menyampaikan pesan dari komunikator kepada khalayak. Keempat, penerima yaitu orang yang menerima pesan (destination / $D$, sasaran penerima pesan). Kelima, umpan balik (feedback) yaitu respon yang diberika oleh komuniken atas pesan yang disampaikan komunikator, bisa berupa umpan balik yang positif atau negatif. Dan keenam, gangguan (noise/ N-S) yang terjadi dalam proses komunikasi akibat perbedaan persepsi, atau daya tangkap (media) penerimanya ${ }^{14}$. Sedangan dalam penjelasan pengantar ilmu komunikasi, ditambahkan signal (tanda, sinyal/ S ) dan receiver (alat penerima/R) ${ }^{15}$.

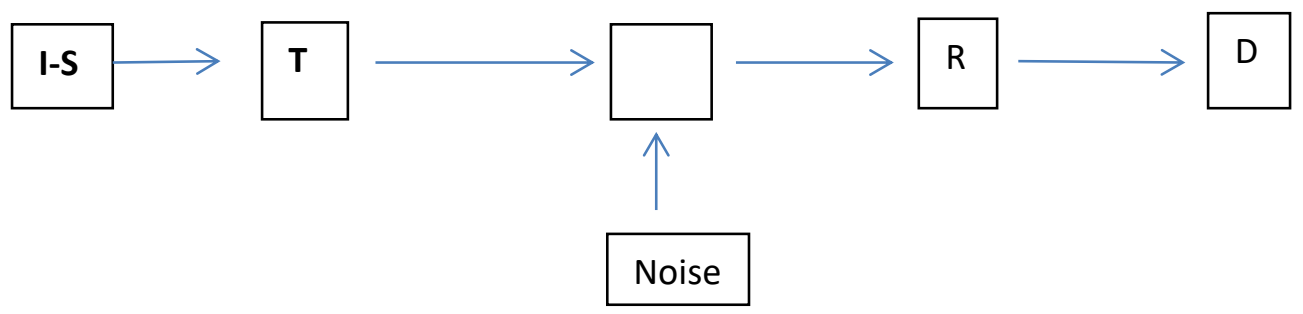

$$
\begin{array}{ll}
\mathbf{I}-\mathbf{S} & =\text { Information source (sumber informasi) } \\
\mathbf{M} & =\text { Message }(\text { pesan) } \\
\mathbf{T} & =\text { Transmiter }(\text { alat saluran penyampaian) } \\
\mathbf{S} & =\text { Signal } \text { (tanda) } \\
\mathbf{R} & =\text { Reciver } \text { (alat penerima) } \\
\mathbf{D} & =\text { Destination } \text { (sasaran penerima pesan) } \\
\mathbf{N}-\mathbf{S} & =\text { Noise source (sumber gangguan) }
\end{array}
$$

Penelitian ini juga coba memberikan sentuhan pada perspektif interaksional, khususnya interaksi simbolis, karena dalam kajian komunikasi pendekatan ini dipandang memiliki sentuhan sisi "manusiawi". Perspektif ini menonjolkan keagungan dan nilai individu diatas nilai pengaruh yang lainya.

\footnotetext{
${ }^{14}$ Rosady Ruslan, Manajemen Public Relation dan Media Komunikasi, Jakarta, RajawaliPers, 2008, hlm. 83

${ }^{15}$ Rayudaswati Budi, Pengantar Ilmu Komunikasi, Kretakupa, Makasar, 2010, hlm. 48-49
} 
Manusia dalam dirinya memiliki esensi kebudayaan, besosialisasi dengan lapisan masyarakat yang majemuk, serta menghasilkan buah pikiran tertentu. Tiap bentuk interaksi sosial itu dimulai dan berakhir dengan mempertimbangkan diri manusia ${ }^{16}$, dengan berbagai sifat, karakter dan ego yang melekat.

Gangguan komunikasi secara umum bisa disebutkan sebagai berikut ; 1) tujuan pesan tersebut tidak jelas, 2) kasalahan pengirim dalam memperkirakan reaksi penerima dan kemampuanya dalam memahami pesan, 3) menyampaikan pesan dengan cara samar dan salah, 4) melakukan proses komunikasi pada waktu yang tidak tepat, 5) gagal dalam menggunakan perangsang ataupun gagal dalam menghubungkan tema bahasan dengan perangsang tersebut, 6) tidak menyimak, mendengar dan tidak perhatian terhadap pesan tersebut, 7) salah dalam menginterpretasikan pesan dan tidak pahan dengan baik, 8) segera menjawab sebelum pesan secara penuh diterima/disampaikan dan 9) rasa malu yang menyebabkan pengirim tidak bisa menyampaikan pesannya dengan baik ${ }^{17}$.

Dalam pemahaman peneliti, isyarat yang paling kentara dalam kondisi mabuk adalah kendala penerimaan pesan, ataupun mengungkapkan pesan tersebut dalam aksi nyata. Kekhawatiran tersebut misalnya tertuang dalam alQur'an,

"Hai orang-orang yang beriman, janganlah kamu salat, sedang kamu dalam keadaan mabuk, sebingga kamu mengerti apa yang kamu ucapkan, ... "18.

Orang yang sedang mabuk mengalami satu kondisi keterputusan aksi, adanya hubungan kondisi mabuk dengan kesadaran terhadap apa yang dilakukan. Mabuk adalah gangguan (noise), ia melumpuhkan sistem media penerima dan pengolah pesan. Sehingga pesan tidak dapat difahami, bahkan sangat mungkin pesan malah disalah fahami. Munculnya keributan, ataupun mengambil keputusan yang tidak rasional, misalnya bunuh diri, merusak, malawan aparat, mengomel sendirian dan hal-hal lain yang tidak biasanya dilakukan oleh orang normal, sedang berfikiran sehat. Proses komunikasi menjadi mengalami gangguan.

${ }^{16}$ Elvinaro Ardian dan Bambang Q, Filsafat Komunikasi, Bandung, Simbiose Rekatama Media, 2016, hlm. 39-40

17 'Awadh M al-Qarny, Hidup Tanpa Beban, Solo, Media Insani, 2006, hlm. 132-133

${ }_{18}$ QS. An-Nisa, 43 
Dalam banyak diskursus Islami, gangguan menjadi penghalang sampainya pesan antara dai (komunikator) dengan mad'u (obyek dakwah). Syeikh Muhammad Nuh memperkenalkanya dengan istilah virus dakwah (افات). Kata beliau, "medan perjuangan dakwah dan jihad dalam menegakkan konsepsi Ilahi dimuka bui ini tidak salamanya berjalan mulus, tetapi sebaliknya, di dalamnya pernuh onak dan duri serta aneka marabahaya, baik yang berasal dari luar ataupun berasal dari dalam”. Penghambat internal tersebut berupa, futhur (terputus/malas), israf (berlebih-lebihan), istijal (buru-buru), takabur (sombong), riya' (pamer secara terang-terangan) dan sum'ah (pamer secara rahasia), i'jab binafsih (merasa senang terhadap diri anpa peduli orang lain) dan masih banyak yang lainya terdiri dari 28 sifat internal ${ }^{19}$.

Dalam banyak ayat, al-qur'an memaparkan berbagai indikasi adanya gangguan kejiwaan, berupa keterpecahan sistem kejiwaan (split personality) yang dapat menghalangi pesan-pesan sampai kedalam jiwa manusia. Misalnya tergambar dalam sifat ; marah (QS. Ali imran, 134), dendam kesumat (QS. Muhammad, 29), dengki (QS. al-Baqarah, 109), takabur (QS. Luqman, 18), suka pamer/riya (QS. an-Nisa, 38), ujub (QS. al-Baqarah, 204), su'udzhan (QS. alHujurat, 12), wass-was (QS. al-A'raf, 20), pendusta (QS. al-Baqarah, 39), rakus/serakah (QS. al-Mukmin, 28), berputus asa (QS. al-Ankabut, 87), pemalas (QS. an-Nisa, 142), kikir (QS. an-Nisa, 47), hilangnya perasaan malu (QS. alAlaq, 14).

Untuk itu diperlukan satu usaha atau terapi Islami terhadap ganguan kejiwaan (mental), agar pesan Islam sampai kepada audien, dalam hal ini para pecandu minuman keras dan sejenisnya. Hal ini perlu dilakukan, karena pada saat setelah melakukannya akan mengalami gangguan kejiwaan yang menyebabkan penghalang sampainya pesan. Sementara pesan-pesan yang sampai akan memberikan pengaruh pada kebaikan jiwa dan menstimulus organ yang memiliki kaitan dengan perubahan dan kecerdasan. Hal ini sejalan dengan firman Allah swt,

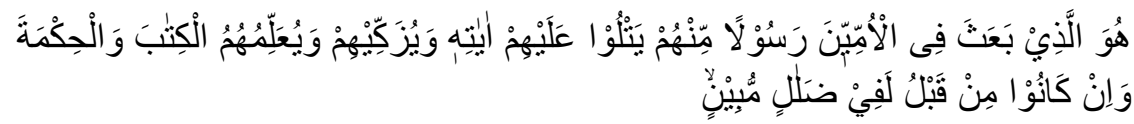

Dialah yang mengutus seorang Rasul kepada kaum yang buta huruf dari kalangan mereka sendiri, yang membacakan kepada mereka ayat-ayat-

${ }^{19}$ Muhammad Nuh, Penyebab Gagalnya Dakwah, GIP, Jakarta, 2000, hlm. 13. 
Nya, menyucikan (jiwa) mereka dan mengajarkan kepada mereka Kitab dan Hikmah (Sunnah), meskipun sebelumnya, mereka benar-benar dalam kesesatan yang nyata. (QS. al-Jumu'ah, 2).

Gangguan sinyal yang terjadi pada aspek fisik diatasi dengan cara melihat bagaimana kerusakan itu, ada pada sistem jaringan yang mana. Demikian juga pada manusia, ternyata juga ada sistem jaringan yang sangat halus, yang terhubung dengan hati sebagai pusat pengolah data. Pada aspek hati inilah perlu dilakukan 'servis' berkala, di bersihkan (tazkiyah an-nafsiyah) pembersihan kejiwaan. Rasul dengan sifat ummi-Nya (buta huruf), dibersihkan jiwanya dengan cara pembacaan ayat-ayat al-Qur'an. Dihaluskan hatinya, agar mampu menangkap nur Islam, pesan yang halus karena bersifat abstrak, tak mampu ditangkap dengan indera mata. Pesan itu, hanya mampu diditeksi dengan perangkat yang lunak, yaitu hati.

Pada sistem hati inilah, sebagai perangkat menyedia alat tangkap pesan itu. Ia harus selalu dijaga dan dinormalisasikan, dihindarkan dari gangguan yang memungkinkan dapat merusak sistemnya. Pemabuk, minuman keras itu telah mampu merusak alat pendeteksi itu, sehingga hilanglah rasa malu, rasa bertanggung jawab. Malah setelah minuman itu berhasil merusah sel perasanya, ia memunculkan virus kesombongan, ada perasaan hebat tak terkalhkan, sehingga muncuk keberanian 'semu' dari para pelaku. Mereka merasa bahwa apa yang dilakukan adalah pilihan yang paling hebat dan tidak merugikan orang lain.

Dalam hubungan pendakwah dengan yang didakwahi, penghambat (noise) tersebut perlu dihindari, diobati dan perlu dibuang dari ekosistem, karena hanya akan membuat tidak sampainya pesan. Ketika pesan tidak sampai, maka hati tidak memiliki bahan untuk didistribusikan ke segala penjuru anggota badan yang memerlukan. Jiwa menjadi keringa, karena aliran syarat tidak ada lagi air yang membasahinya, yaitu berupa pesan. Pesan berhenti karena adanya gangguan yang menghambat atau mungkin merusak pesan.

Al-Qur'an berpesan, menyuruh manusia melalui kalam berita (kalam khabar) agar menjadikan wahyu Allah sebagai obat. Karena orang yang mengalami mabuk, ia sejatinya sedang hilang akal (daya pikirnya) sebagai syarat sah melaksanakan perintah syari'at. Pesan tersebut mengandung pesan diatas,

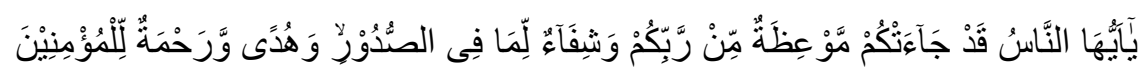


Wahai manusia! Sungguh, telah datang kepadamu pelajaran (Al-Qur'an) dari Tuhanmu, penyembuh bagi penyakit yang ada dalam dada dan petunjuk serta rahmat bagi orang yang beriman. (Yunus, $10: 57$ )

Menjadi semakin jelas, bahwa macetnya informasi kepada manusia dengan organ yang rusak, terutama pada organ yang sangat halus, yaitu jiwa. Kata Yasien, meskipun manusia terlahir dalam keadaan fitrah, tetapi dia juga memiliki potensi untuk salah. . . Perbuatan yang salah, kekufuran, dan pelanggaran terhadap hukum Tuhan adalah ciptaanNya. Tetapi Allah juga menciptakan kemampuan untuk membedakan yang benar dari yang salah. Dorongan-dorongan emosional dan biologis manusia secara inheren tidak jahat, tetapi mudah menerima rangsangan jahat. Mereka perlu dikendalikan dan diarahkan sesuai hukum-hukum yang telah ditetapkan secara Ilahiyah sehingg nafsu bisa ditranspormasi kepada tingkatatan tertinggi dari spiritual -almuthma'innah. ${ }^{20}$

Para sarjana Barat juga memberikan perhatian terhadap situasi bertambahnya pecandu dan korban minuman keras, dimana semakin dirasakan merusak generasi dan memerlukan penanganan yang tidak ringan. Fenomena ini mengkawatirkan bagi pertumbuhan penduduk yang sehat dan berimbang dengan tanggung-jawabnya mengurus negara dan pemerintahan. Para pecandu, tentu tidak peduli lagi pada kelahiran bayi, demikian juga dengan perawatannya. Hal ini dimotivasi pada pragmatisme kesenangan sesaat yang kemudian malah beribah menjadi mala-petaka bagi kehidupan normal. Seks bebas dan bunuh diri menjadi semacam pilihan membangun kesenangan dan juga bagaimana mengakhiri hidup yang dirasakan hanya sebagai beban saja. Pilihan itu karena rusaknya sistem berfikir dan hilangnya moral dalam kehidupan.

Menarik survei yang dilakukan Weekly Reader (1987), menyoroti pada apa yang membuat anak-anak usia sekolah dasar terlibat narkoba. Untuk anak usia kelas $4-6$, alasan paling penting adalah sebagai sarana untuk menumbuhkan perasaan ; 1) cocok dengan orang lain, 2) untuk bersenangsenang, dan 3) Keinginan merasa lebih tua ${ }^{21}$. Satu gambaran yang coba melukiskan bagaimana pengaruh miras dan sejenisnya, telah mengubah satu pandangan hidup yang hanya menekanan kesenangan dunia. Pilihan menggunakan minuman keras, coba ditempuh sebagai media membangun

${ }^{20}$ Yasien Muhammad, Insan Yang Suci, Mizan, Bandung, 1997, hlm. 107-108

21 Thomas Lickona, hlm. 532-534 
interaksi sosial. Dalam aktifitas meminumnya, mengambarkan satu 'simbol' keeratan dan tentu perasaan merasa senang dan tenang.

Maka saat komunikasi akan dibangun, melibatkan obyek komunikasi sebagai penerima, memang tidak bolah hanya berhenti pada aspek fisiknya. Karena manusia memiliki sistem jiwa dan sistem raga yang saling mendukung dan juga memiliki fungsi masing-masing, maka diperlukan satu perhatian, bagaimana jiwa manusia (hati) juga harus disiapkan sebagai alat penerima. Jiwa bukan sekedar stasiun penghubung, alat bantu penyampai pesan, tetapi juga sekaligus alat pengolah dan pendistribusi pesan itu. Bahkan, dalam situasi yang lain, jiwa juga berfungsi sebagai alat control, evaluasi terhadap pesan yang masuk dan yang akan keluar.

Thomas Lickona mencoba melakukan beberapa saran, pada pendidikan remaja perlu ditekankan hubungan yang hangat, manusiawi, dan sesuai dengan jiwa peserta. Pembina harus memberikan fasilitas yang memungkin pembicaraan tentang permasalahannya dan menjadi pembimbing moral ${ }^{22}$. Beberapa variabel diatas perlu ditekankan, agar berubah menajadi dasar motivasi bagi semangat untuk terus memperbaiki diri dari keterpurukan moral. Motivasi harus didekatkan dengan nilai moral. Dalam kajian peradaban Timur, moral bermakna agama yang sifatnya sampai pada puncak keyakinan.

Pada pendekatan motivasi, kita bisa memberikan perhatian terhadap masalah diatas sekurangnya pada 3 faktor utama. Pertama, keterlibatan atau relevansi personal dengan topik. Semakin penting topik tersebut bagi audien secara pribadi, mungkin audien semakin berfikir secara kritis tentang isu yang terlibat. Kedua, adanya perbedaan pendapat. Audien cenderung akan lebih memikirkan pendapat yang berasal dari beragam sumber. Hal ini terjadi karena ketika audien mendengar beberapa orang membicarakan tetang sebuah isu, audien tidak dapat membuat penilaian dengan sangat mudah. Hal-hal lain menjadi setara, dimana beragam sumber dan pendapat terlibat, penerima cenderung mengoah informasi secara sentral. Ketiga, dalam motivasi adanya kecenderungan pribadi audien terhadap cara berfikir kritis. Orang yang suka mempertimbangkan pendapat, mungkin akan lebih menggunakan pengolahan secara sentral daripada mereka yang tidak suka terhadap hal tersebut ${ }^{23}$.

\footnotetext{
22 Thomas Lickona, hlm. 116

${ }^{23}$ Steven W.L dan Karen A.F, Teori Komunikasi, Salemba Humanika, Jakarta, 2011,
} hlm. 109 
Pada pecandu, pengolahan sentral inilah yang mengalami masalah paling mendasar. Tindakan-tindakan yang diambil, sangat dipengaruhi oleh motivasi jiwanya. Kecenderungan melakukan sek bebas, semakin menguat dan liar saat pecandu memakai barang terlarang tersebut. Kesadarannya dikuasai oleh motivasi apa yang paling dominan, baik pada hatinya ataupun pikirannya. Mana yang mendominasi pengolahan motivasi sampai pada saat keputusan diambil. Namun demikian, sebagaimana kesimpulan Dadang, karena dampak pemabuk mengakibatkan perubahan perilaku, diperlukan motivasi yang lebih kuat dan dominan. Hal tersebut untuk mengganjal laju motivasi jelek, sekaligus membuka pintu bagi pengembangan motivasi yang baik. Karena jika, motivasi jelak semakin dominan, tindakan perkelahian dan tindak kekerasan lainnya akan merusak. Hal ini muncul karena adanya ketidak-mampuan menilai realitas (hilangnya daya nilai) untuk menentukan mana yang baik dan mana yang buru, dibenaknya hanya tergambar aspek kepuasan pribadi. Ia tidak merasa apa yang dilakukan dapat menibulkan gangguan dalam fungsi sosial.

Terapi kesabaran harus ditumbuhkan, demikian juga terapi sifat merusak kondisi sosial. Dalam pesan Rasul malah ditekankan, bahwa situasi sosial yang kondusif memerlukan bangunan iman yang berdimensi Ilahiyah dan juga dimensi kehidupan akhirat. Akhirat dipersiapkan menjadi tepat yang baik karena sebab amal baik, bukan menjadi beban karena kesalahan memilih kehidupan dunia yang diciptakan dengan beraneka ragam situasinya, yang jahat dan baik bercampur. Sulit dipisahkan, jika ahanya bermodal putus asa, mabuk dan akhirnya bunuh diri. Islam melihat kondisi apapun, termauk kondisi jahat tetap bisa dirubah menjadi baik. Bagaimana caranya? Tentukan niat untuk berhenti dari dosa, dan sekaligus pilih perbuatan yang paling baik dari perintah Allah yang ada ini. Doktrin Islam mengetengahkan dalil Rabbani,

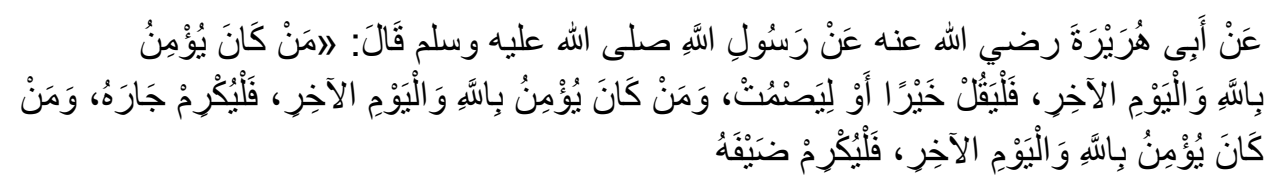

Dari Abu Hurairah RA bahwa Rasulullah SAW bersabda, "Barang siapa beriman kepada Allah dan Hari Akhir, hendaklah ia berkata baik atau diam; barang siapa beriman kepada Allah dan Hari Akhir, hendaklah ia menghormati tetangganya; barang siapa beriman kepada Allah dan Hari Akhir, hendaklah ia memuliakan tamunya." (HR Bukhari Muslim) 
Pelaku harus ditumbuhkan untuk selalu termotivasi dengan pilihan pekerjaan yang baik, yang terkoneksi dengan moral agama. Dengan cara ini mereka akan tumbuh gejala psikologik yaitu perubahan perasaan (afektif), sehingga motivasi bunuh diri menjadi semakin berkurang dan akhirnya menghilang. Demikian juga dengan kondisi mudah marah dan tersinggung (iritabilitas) yang memang menjadi ciri dominan bagi pemabuk. Panasnya minuman keras itulah yang mendorong perilaku kasar dan tidak manusiawi. Kekasaran yang ditimbulkan berupa efek yang kurang baik, terutama pada kasus banyak bicara (ngelantur). Sentral pikiran tidak lagi fokus, karena motivasi kesenangan mengalahkan bagaimana proses kehidupa ini diraih. Kondisikondisi tersebut menjadi masalah krusial karena telah berhasil dan menguasai isu perbaikan.

Jika dalam perbincangan komunikasi umum, gangguan lebih bersifat teknis sistem penerimaan pesan berupa server, tapi tidak dalam perspektif dakwah. Dalam dakwah perilaku bermain-main, bahkan sinis terhadap kebenaran adalah buah dari hubungan yang kurang harmonis. Entah siapa yang melakukan, komuikator (da'i), ataupun dalam obyek serta proses sampainya pesan. Pertanyaannya, masih mungkin dilakukan perbaikan? Terutama perbaikan pada budaya kehidupan bermasyarakat, dipelukan kesadaran untuk memperbaiki gangguan perhatian/konsentrasi. Kehilangan konsentrasi, dalam kehidupan metropolitan yang padat hanya akan meninggalkan cerita kelabu, dimana kecelakaan lalu lintas menjadi sesuatu yang sudah mulai dianggap biasa.

Motivasi dalam gerak penanganan korban pecandu, lebih menekankan diri pada situasi yang keterhubungan kecocokan ide, kawan yang telah duluan bertobat akan menempati posisi pertama sebagai pembawa pesan. Kedekatan emosional secara manusiawi telah menguat menjadi motivasi untuk mengikuti ajakan dan selanjutnya melakukan perubahan. Potensi diri yang telah tertanam dalam alam ruh, muncul dan menguat, mendorong pilihan yang baik saat informasi ditangkap. Jadi, mengobati kejiwaan, memiliki makna menghilangkan gangguan yang dapat memperlambat dan mungkin menghentikan transfer informasi yang diperlukan.

Dalam hal tersebut, dalam hadist yang diriwayatkan oleh Abu Hurairah bahwa Rasulullah shallallahu 'alaihi wasallam bersabda: 


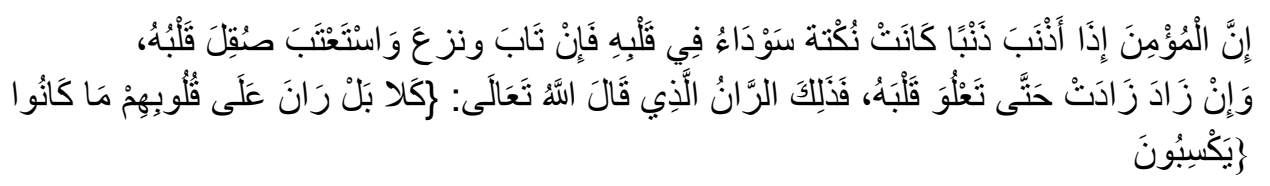

"Seungguhnya seorang mukmin, jika ia mengerjakan suatu perbuatan dosa, maka akan timbul noda hitam dalam hatinya. Jika ia bertaubat, menarik diri dari dosa itu, dan mencari ridha Allah, maka hatinya menjadi jernah. Jika dosanya bertambah, maka bertambah pula noda itu sehingga memenuhi hatinya. Itulah ar-ran (penutup), yang disebut oleh Allah Ta'ala dalam firman-Nya: "Sekali-kali tidak (demikian), sebenarnya apa yang selalu mereka usahakan itu menutupi hati mereka." (HR. Imam At-Tirmidzi, Nasai dan Ibnu Majah. Imam Tirmidzi mengatakan bahwa hadis ini hasan sahih)

Noda hitam itulah dosa, semakin hari akan semakin menutupi putihnya hati. Maka perlu siraman atau usaha untuk menghapsunya sedikit demi sedikit. Tujuanya agar area putih masih terlihat, atau bisa semakin luas. Dalam alur komunikasi juga demikian, diperlukan jalur yang bebas hambatan sehingga perjalanan informasi lancar, dalam kondisi utuh sampai penerima. Pun demikian si-penerima itu sendiri, juga harus dalam suasana yang nyaman saat menerima pesan tersebut. Kondisi jiwa harus mencerminkan kondisi yang kondusif bagi obrolan yang mengandung pesan Ilahi yang maha suci.

Niat ingin memperbaiki diri, ingin taubat, menebus kesalahan adalah faktor yang tumbuh dari keyakinan, adanya dalam hati sebagai sebuah kecenderungan atau arahan yang berpangkla pada dorongan Rabbaniyah dalam rangka melakukan pekerjaan tertentu. Dari niat inilah, muncul motivasi tadi, yang timbul sebagai implikasi dari adanya niat, yang kemudian menuntut pemikiran atas suatu pekerjaan dan merealisasikannya. Dalam kajian psikologi Islam motivasi terbagi yang bersifat naluriah dan bersifat kognitif ${ }^{24}$.

Motivasi naluriah didominasi aspek biologis, dunia hewan banyak dipengaruhi oleh hal tersebut. Kebebasaan, ditunjukkan dengan gambaran sek bebas kepada lawan jenisnya, tak ada hukum sosial yang mengaturnya, pun juga pendidikan dalam masalah tersebut. Kajian pada dorongan biologis, memfokuskan pada bahasan insting, dorongan hawa nafsu hewani. Kondisi seperti, mungkin memiliki kecenderungan yang sama saat pecandu kehilangan

${ }^{24}$ Muhammad Izzuddin Taufiq, Psikologi Islam, GIP, 2000, hlm. 657 
daya ingatnya karena mabuk, maka yang mendominasi informasi adalah pikiran bawah ambang sadar yang tidak terkoneksi dengan sistim kontrol manusia. Motivasinya didominasi pada motif lapar, haus, tidur dan istirahat, bernafas, seksual dan lain-lain. Sebagai modal dasar, motif biologis mendorong manusia, atau makhluk hidup menjadi lebih kreatis, asal tidak boleh hanya berhenti dengan kondisi seperti ini. Ia harus diarahkan sebagai proses edukasi.

Selain motivasi naluriah, diskusi untuk al tersebut juga memilihkan term aktif, sehingga menyebutnya dengan motif kognitif. Motif ini tidak menggunakan variabel sifat biologis dalam diri manusia. Ia lebih menekankan pada kondisi kejiwaan manusia, saat menjadi teman memilih kebaikan dan juga menyingkirkan keburukan. Motivasi ini tidak memiliki akses kepada anggota fisik, tapi lebih didominasi oleh keperluan kejiwaan. Dimana misalnya, seorang anak murid diberikan pelajaran tantang baik-buruk. Dipelajarinya hal tersebut lebih karena manusia akan berinteraksi dengan banyak orang, sehingga perlu konten yang sama. Kesamaan itu akan memudahkan saling memahami dan mungkin juga saling menutupi kekurangan.

Jiwa pecandu dapat dibina, diarahkan ke kondisi yang lebih baik dari sebelumnya. Dimana tujuan dari motif kognitif sebagai cara untuk menjaga diri dan mengembangkan kemampuan. Dibandingkan sifat biologis, motivasi kognitif memang lebih rumit, karena dimulai dari proses mengenali dan membuat antisipasi yang bercorak manusiawi. Dengan memenuhkan nilai-nilai yang baik pada memori pecandu, diharapkan akan mengubah persepsi baik dan buruk menurut kemauan pecandu. Saat hati sudah merasakan nyaman atas dasar-dasar Islami, maka pertumbuhann kearah perbaikan jiwa dapat terpenuhkan, sehigga akan berkembang keseimbangan kejiwaan.

Menurut Muhammad 'Usman Najati, "kondisi orang-orang yang mendertita penyakit kejiwaan bisa digambarkan dalam tiga kelompok besar; yakni mengalami kebingungan pada dirinya sendiri dan orang lain, berperilaku tak pantas dan merasa dirinya sengsara ${ }^{25}$. Kita suka memperhatikan bagaiamana perilaku yang tidak wajar tampil dalam diri seorang pecandu narkoba. 'Menyebalkan' karena menghilangkan estetika kehidupan manusia normal, menakutkan bagi anak-anak dan kaum wanita, kerana takut dengan aksinya yang tidak mudah diprediksi. Sementara manusia normal sejatinya juga ingin menolongnya dan memberikan perhatian, tapi terhalang oleh skil yang tidak

${ }^{25}$ Ridwan, Konseling dan Terapi Qur'ani, Pustaka Pelajar, Yigyakarta, 2018, hlm. 14 
mencukupi bagaimana mempergauli mereka. Situasi yang sulit ini, boleh jadi akan memberikan pengaruh yang lebih serius bagi kembalinya kondisi normal daya tangkap dan kemampuan mengolah informasi yang masuk. Karena pada situasi tertentu, para pecandu tidak selamanya dalam kondisi mabuk, mungkin saja ada waktu-waktu tertentu mereka sadar. Tapi apa daya, orang-orang disekeliling mereka telah menjauh karena sebab takut, atau karena merasa tidak memiliki kemampuan untuk membangun komunikasi secara normal.

Memang sangat bisa difahami dalam kelompok perilaku menyimpang, pemabuk berada dalam situasi yang tidak stabil. Walaupun tidak tepat, memasukkannya dalam kelompok kondisi anak kecil, tapi dari sisi tidak sempurnanya akal, nampak para kecanduan narkoba memang kondisi akalnya sedang bermasalah. Maka ayat menyebutkan, “ . . janganlah kamu salat , sedang kamu dalam keadaan mabuk, sehingga kamu mengerti apa yang kamu ucapkan, . . ",26. Dalam kajian fiqh ibadah, akal menjadi dasar beban hukum itu menuntut dilaksanakan. Terlihat dari sifat mumayyiz yakni dapat membedakan mana yang baik dan mana yang tidak. Kedaan sadar memabantu mengerti apa yang harus dibaca, dikerjakan dan apa makna didalamnya.

Kesadaran pecandu narkoba ditumbuhkan melalaui pembinaan yang intensif, disinilah motif kognitif mendapat kesempatan. Dalam banyak komunitas rehabilitasi korban kecanduan narkoba dan miuman keras, para pelaku dilatih untuk konsentrasi. Diajak mereka melakukan pendekatan diri lebih awal melalui ibadah dan doa, sebagai bentuk latihan jiwa. Bagaimana keinginan mereka "bunuh diri" disambungkan dengan soal kematian. Disadarkan bahwa kematian buka sebagai cara melepaskan beban, tetapi pada kematian manusia harus mempertanggung-jawabkan seluruh perbuatannya. Nilai-nilai soal bagimana hidup ini memiliki nilai manfaat adalah cara penumbuhkan kesadaran diri pecandu. Mereka diberikan motivasi yang terus menerus melalui dialog secara pribadi, digali apa maunya, diarahkan emosinya ke motif positif.

Dalam kajian yang lebih memperhatikan perubahan jiwa dan raga, tokoh dakwah semisal Al-Bayanuni dalam kitab al-madkhal ila ilmi da'wah dan juga Khalid bin Muhammad degan kitabnya Silsilah Ummatu al-Mu'minin wa alDakwaah ila Allah, telah berhasil mengurai dan memberikan banyak contoh pendekatan pembinaan melalui tiga cara ; uslub 'aqli (kognitif), uslub 'atifi (afeletif)

${ }^{26}$ QS. An-Nisa, 43 
dan uslub hissiyah (media fisik melalui latihan). Ketiga cara ini sangat mendukung usaha mendidik dalam mengatasi gangguan (noise) yang menjadi masalah bagi para pecandu. Usaha-usaha perbaikan jiwa pecandu bisa didekati dengan memotivasinya melalui potensi kecerdasan, potensi perasaan dan dihidupkan situasi pembiasaan melalui latihan-latihan.

Pada aspek kognitif sejalan dengan bagaimana Allah memerintahkan manusia untuk menggunakan akalnya, memikirkan ang Pencipta, alam serta dirinya. Bagaimana Allah menciptakan diri manusia dengan sungguh-sungguh, amak demikian pula manusia harus memnafaatkan dengan kesungguhan keberadaan dirinya. Bekal akal, yag terlihat dari tutur katanya serta karya-karya nyatanya digunakan tidak hanya sekedar untuk memecahkan kehidupannya saja, ataupun hanya sekedar untuk alat adaptasi dengan lingkungannya? Didalamnya sejatinya terdapat misi yang lebih bermartabat, yaitu sebagai sarana mengevaluasi diri sehingga selalu berusaha memperbaiki dirinya. Bahwa saat menghadap Allah, saat mati dan setelahnya, akan memudahkan mempertanggung-jawabakannya dihadapanNya.

Modal kecerdasan dalam dimensi interaksi sosial, adalah media koneksitas hubungan antar manusia dan juga koneksi imbal balik dalam dialog dua arah, bahkan banyak arah. Kecerdasan adalah basyirah, kesadaran kognitif sebagai prasyarat menyelami pengetahuan agama yang luas dan penuh tanggung-jawab. Tumbuhnya kesadaran akan memudahkan transmisi penangkap pesan dalam sistem komunikasi mampu memnyimpan data dan mengolahnya untuk didistribusikan. Pecandu yang mulai tumbuh sistem kesadarannya selanjutkan akan mengolah kecerdasannya mengatahui isi pesan, membidangkan pesan itu ada dikelompok mana menjadi lebih logis, difahami isi sari patinya, lalu diteruskan isi tersebut menjadi suatu konsep memanusiakan dirinya dihadapan Allah. Kecerdasan dari Allah inilah kemudian memberikan makna bagi maksud Allah bahwa "memberi hidup dan menghidupkan" (lima yuhyiikum), sebagaimana kata Natsir ${ }^{27}$.

Usaha memperbaiki gangguan harus juga melibatkan aspek perasaan (afektif). Kelebihan manusi diberikan organ hati dan akal, agar tumbuh juga dalam diri manusia suatu situasi atau suasana yang estetik adanya sentuhan keindahan. Pecandu narkoba sebagaimana banyak hasil penelitian, seringkali menampilan sifat kasar, beringas, gambpang tersinggung dan pikiran pendek,

${ }^{27}$ M. Natsir, Fiqh Dakwah, Media Dakwah, Jakarta, 2006, hlm. 148 
adalah gambaran tentang hilangnya nilai estetika. Mereka terjebak koneksi hitam putih saja, hal tersebut karena terjadi semcam 'mati rasa' pada sel perasaan. Mereka sulit atau mengalami kebuntuan saluran informasi yang aspeknya menyentuh bidang keindahan. Padahal hidup ini perlu dan harus diberikan sentuhan estetika yang baik. Kecenderungan estetika tersebut untuk mendorong rasa jenuh, bosan, dan selalu berfikiran negatif bagi perkembangan perasaan manusia. Dengan keindahan, saraf itu akan mendorong seluruh panca-indera berkontribusi bagi tumbuhnya 'rasa nikmat' yang harus ada dalam kehidupan seseorang. Dari rasa keindahan inilah, unsur-unsur manusiawinya menjadi sarana untuk membangun kembali kesempurnaan ciptaan Allah ini.

Karena hidup ini indah, maka para pecandu didorong untuk rajin mandi kerena tubuh perlu ditampilan dalam kondisi yang nyaman bagi aktivitas yang lebih produktif, menghilangkan kemalasan dan tentu jadwal mandi adalah bagian dari tertib menyongsong kehidupan. Mandi peneliti ungkapkan, karena para pecandu pada umumnya takut dengan air, karena dianggap akan membuat fisik menjadi sakit. Sehingga mandi atau air akan dijauhi. Padahal kecermelangan pikiran, tumbuhnya kesadaran dapat dimulai dari interaksinya dengan air. Maka manusia juga diciptakan dari air, demikian juga dengan kehidupan ini. Sebagai gambaran bagaimana peristiwa seorang kafir masuk Islam, diantara tata caranya adalah melalui mandi. Satu perkenalan koneksi komunikasi, bahwa usaha perbaikan yang ada dalam tradisi Islam selalu berkaitan dengan air. Dibasahinya dahi saat berwudhu adalah awal interaksi komunikasi ilahiyah. Akal dan hati dihaluskan dengan air suci, dan untuk tujuan yang lebih suci lagi yaitu membangun ketaatan kepada Allah.

Air dalam peristiwa wudhu dapat memberikan manfaat yag sangat banyak. Afif dan Uswatun Hasanah melakukan penelitian terhadap Hadist Rasulullah tentang wudhu dengan pendekatan makna teks. Merka menyimpulkan, "cara wudhu terhadap kesehatan adalah dapat membersihkan berbagai kotoran, virus, dan bakteri yang berada di telinga, hidung, mulut dan gigi, serta dapat mempermudah regenerasi selaput lendir sehingga dapat mencegah berbagai penyakit yang masuk melalui telinga, hidung dan mulut, baik penyakit yang ringan maupun penyakit yang serius. Selain itu, kebanyakan titik refleksi berada pada anggota wudhu ${ }^{28}$. Beberapa gejala yang

\footnotetext{
28 journal.stainkudus.ac.id/index.php/RiwayahDOI: -Volume 2 Nomor 2016ISSN: 2460-755Xe-ISSN: 2502-8839Urgensi Wudhu dan Relevansinya Bagi Kesehatan (Kajian Ma'anil Hadits) dalam Perspektif Imam Musbikin
} 
muncul dari pemabuk, seperti gemetaran, kurang teliti, 'deg-degan (jantung berdebar) dan takut air akan membantunya memulihkan dan mengendorkan saraf yang kaku.

Aspek kecerdasan dan perasaan yang dimiliki pelaku, akan semakin meningkat dan konsisten manakala terus dibiasakan, dilatih (hisiyyah) dengan tertib. Latihan dan pembiasaaan akan menormalkan kondisi yang sebelumnya menjadi penghalang bagi proses komunikasi. Saraf perasaan akan kembali pada jalur semula serta dapat diajak beraktivitas sebagaimana biasanya. Seperti jaringan kabel komunikasi yang memerlukan rekondisi karena sudah lewat masa pakai, ataupun karena terjadi masalah jaringan. Dengan pembiasaan yang kontinyu, penuh kesabaran dari para pembimbing yang berpengalaman akan memudahkan pulihnya keadaan. Pelibatan dalam skala kecil yang konsisten, akan membantu pelaku dalam beradaptasi dengan lingkungan dialog, dan pada waktunya akan lebih berani secara mandiri dalam menyikapi situasi.

Bagi pecandu dalam banyak kisah, situasi yang paling berat dalam proses penyembuhan adalah dorongan serta ajakan untk kembali ke habita awalnya. Untuk menyikapi persoalan ini, perlu dicarikan komunitas baru sebagai tempat hijrah, melepaskan kebiasaan lama dan bercengkrama dengan masyarakat yang baru. Dikembalikan ke dalam suasana fitrah, sehingga sifat malu, ragu-ragu, gemetaran dan mungkin keiinginan mengulang kesalahan menjadi tidak mungkin lagi. Kerja-sama keluarga menjadi enyokong utamanya, karena kepindahan pastilah akan juga berpengaruh pada perubahan tradisi dan budaya bermasyarakat, serta persoalan kerja karena lingkungan yang baru. Tapi keputusan pindah memang harus diambil sabagai konsekuensi pilihan untuk sembuh. Lingkungan akan memberikan pengaruh yang sangat kuat, laksana pertemanan tukang minyak wangi akan mendapat wanginya, dan berteman dengan tukang pandai besi akan mendapatkan percikan api dan bau yang tidak sedap. Rasululullah mengingatkan dalam hadistNya,

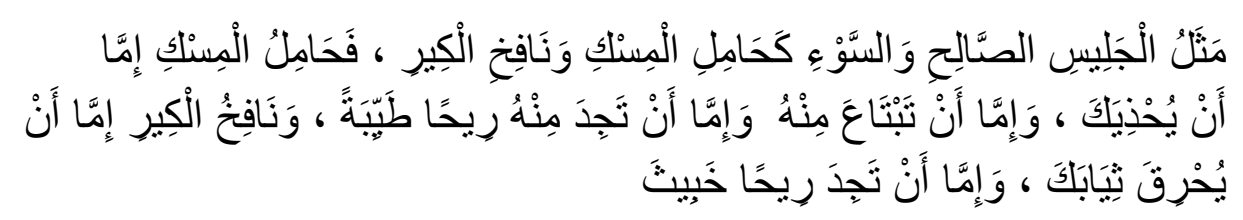

"Permisalan teman yang baik dan teman yang buruk ibarat seorang penjual minyak wangi dan seorang pandai besi. Penjual minyak wangi mungkin akan memberimu minyak wangi, atau engkau bisa membeli 
minyak wangi darinya, dan kalaupun tidak, engkau tetap mendapatkan bau harum darinya. Sedangkan pandai besi, bisa jadi (percikan apinya) mengenai pakaianmu, dan kalaupun tidak engkau tetap mendapatkan bau asapnya yang tak sedap.” (HR. Bukhari 5534 dan Muslim 2628)

Maka terapi-terapi yang mampu mendekatakn jiwa mereka semakin halus dan mampu bergetar saat mendengar ajakan kebaikan harus dimaksimalkan. Terapi Qur'ani melalui ruqyah, doa pribadi, didekatkan untk berinteraksi dengan al-Qur'an dalam arti bisa membaca dan merenungkan ayatayatnya, serta diajak untuk terlibat dalam kegiatan bermasyarakat, adalah beberapa cara memulihkan mental mereka. Secara rutin diajak shalat jama'ah di Masjid, menghadiri tilawatul al-Qur'an, mendengarkan doa dan membiasakan doa dalam berbagai aktivitas. Tentu terus diajak meningkatkan ibadah kepada Allah, baik yang fardhu ataupun yang sunnah.

Usaha-usaha ini dalam rangkan menormalkan kembali jaringan saraf pecandu agar lentur kembali. Juga untuk mengembalikan kebiasaan baik yang selama ini telah tertutupi atau terhalang karena suka mabuk. Do'a dalam makna yang luas, tidak sekedar dimaknai permintaan, tapi juga hubungan yang erat antara seseorang dengan Allah akan menempatkan seseorang dalam kondisi yang baik. Doa akan menjadi senjata yang mampu menaklukkan virus penghambat komunikasi, juga akan menguatkan agama serta menjadi penerang kehidupan. Dalam kita Al-Dau wa al-Dawa' karya Ibn Qayyim, Rasulullah shallallahu 'alaihi wa sallam yang diriwayatkan dari Ali bin Abi Thalib radliallahu 'anh sebagai berikut:

\section{الدعاء سلاح المؤمن، و عماد الدين، ونور السماوات و الأرض29}

Artinya: "Doa adalah senjata seorang Mukmin dan tiang (pilar) agama serta cahaya langit dan bumi. (HR. Al-Hakim).

Pendekatan agama, dalam hal ini mengembalikan kondisi kepada panduan kehidupan yang Rabbaniyah, yaitu dikembalikan sesuai bimbingan alQur'an dan sunnah sehingga sesuai dengan apa yang dikehendaki Allah sang pencinta manusia dan wahyu. Usaha ini dilakukan agar memudahkan penanganan kondisi saraf kembali nomal, juga pikiran dan hati kembali fitrah. Sebagaimana dalam bahasan yang telah lewat, al-Qur'an adalah obat bagi jiwa,

\footnotetext{
${ }^{29}$ Ibn Qayyim, Al-Daa wa Dawa', Daaru ibn al-Jauzi, Mesir, hlm. 10
} 
melatih kepekaan akan kebenaran yang disuarakan melalui para juru dakwah, menggetarkan jiwa yang sebelumnya keras. Mengembalikan fitrah Ilahiyah ini memiliki strategis, karena jiwa pernah berjanji sejak di alam ruh bahwa Allah adalah Rab bagi manusia dana alam ini ${ }^{30}$. Seperti masa kecil yang suci, sehingga seluruh kebaikan-kebaikannya yang ada ini, menjadi sarana yang memudahkan menangkap pesan Ilahi. Tak pernah protes dan berhenti mengikuti contoh orang tua dan guru. Seperti kertas putih, yang terserah coretan apa yang akan digoreskan, jelas terlihat.

Begitulah jika jiwa selalu bersih dan harus dibersihkan agar pesan mudah diakses dan diolah. Pemabuk tak sepantasnya diposisikan sebagai sampah masyarakat, mereka memiliki hati yang perlu dibersihkan, agar kembali normal mengikuti ajakan. Kekotoran jiwanya harus disingkirkan agar pesan lancar sampai pada maksudnya dan meneruskanya ke anggota badan yang lainnya. Kebaikan-kebaikan yang terus diingatkan kepada pecandu, dilatihkan terusmenerus akan dapat menghapus dosa dan kesalahan, seperti percikan tinta di air yang akan membuat hitam. Saat air diguyurkan terus-menerus, maka air yang sudah hitam akan digeser oleh aliran air bersih itu. Selanjutnya, yang tersisa hanyalah kebersihan jiwa dan siap menerima masukan yang baru.

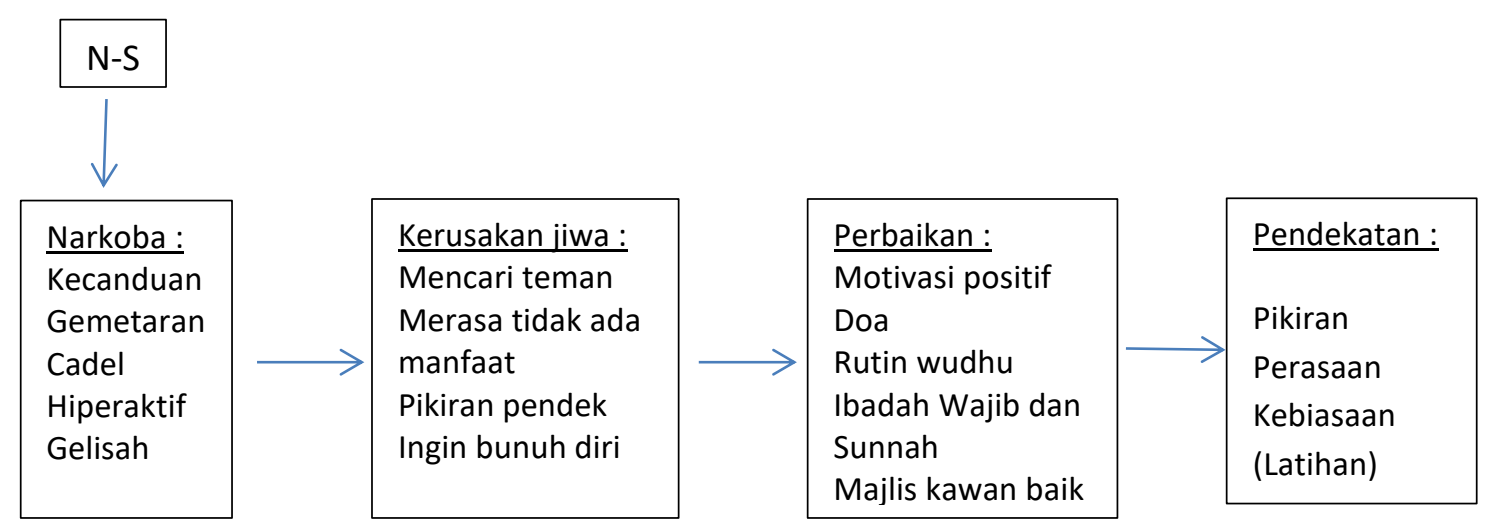

(Proses deteksi dan penanganan noise)

Perawatan jaringan informasi menjadi satu kesatuan dari keseluruhan proses komunikasi. Kendala gangguan sampainya pesan harus diditeksi dan ditangani setiap saat,-karena jika tidak tertangani- maka akan membuat tidak

${ }^{30}$ QS. Al-A'raf, 7: 172

57 | Dakwah | Vol 4 | No. 1 | 2021 
berfungsinya proses komunikasi tersebut sebagai suatu usaha perbaikan. Penanganan gangguan sistem informasi dalam diri manusia, dipilih dengan mempertimbangkan aspek mana yang perlu ditangani. Jika gengguan itu adalah jiwanya, maka usaha tersebut dikenal dengan tarkiyatu nafs (pembersihan jiwa) sebagaimana bimbingan wahyu. Kerusakan jiwa tersebut bisa dikelompokkan dalam aspek pikirannya, perasaanya dan tentu kebiasaan-kebiasaannya

\section{KESIMPULAN}

Manusia dicipta dengan sempurna, melewati proses yang panjang, melewati perjalanan yang panjang dan kadang persimpangan yang tajam. Mereka memerlukan jaringan infomasi yang sehat sebagai sarana membangun dialog dan komunikasi. Namun, potensi diri yang tidak baik menjadikan saluran informasi terhambat untuk menerima dan mengolah pesan. Minuman keras telah menjadi sebab permulaan kerusakan sel kognitif, dan afektif sebagai organ yang paling penting saat menerima pesan Allah. Ia telah mengganggu, kehidupan manusia normal, berubahlah jiwa tersebut terseret dalam seksualitas yang bebas serta keinginan mengakhiri hidup dengan bunuh diri, saat jiwa tak mampu mengatasi kekecewaan. Trennya masih tinggi dan terus bertambah, karena kepantingan ekonomi, kesenangan dan gengsi sosial menjadi doktrin pragmatis alam materi. Harus diatasi, karena kehidupan masih diperlukan manusia sebagai sarana ibadah dan memperbaiki diri,

Dalam diskursus komunikasi ia menjadi gangguan (noise) yang akan menghambat dan mungkin merusak pesan. Perlu perbaikan untuk menyembuhkannya kembali kepada semula. Penyembuhan gangguan kejiwaan diarahkan ke cara Qur'ani sebagaimana tujuannya, yaitu diturunkan sebagai pedoman hidup. Melalui do'a, ibadah, memahami kandungannya dan berusaha melatih jiwa dan fisik dalam amal kesehariannya. Penanganan kejiwaan meliputi tiga aspek ; pikiran melalui stimulus ilmu, perasaaan melaui perenungan kejiwaan dan dilatihkan terus-menerus agar kebiasaan kembali normal.

\section{DAFTAR PUSTAKA}

Al-Quran Depag, online 
Hadist Nabi online

‘Awadh M al-Qarny, Hidup Tanpa Beban, Solo, Media Insani, 2006

Dadang Hawari, Al-Quran Ilmu Kedokteran Jiwa dan Kesehatan Jiwa, Dana Bakti Primayasa, Yogyakarta, 1999

Elvinaro Ardian dan Bambang Q, Filsafat Komunikasi, Bandung, Simbiose Rekatama Media, 2016

Ibn Qayyim, Al-Daa wa Dawa', Daaru ibn al-Jauzi, Mesir, tanpa tahun

M. Natsir, Fiqh Dakwah, Media Dakwah, Jakarta, 2006

Muhammad Izzuddin Taufiq, Psikologi Islam, GIP, 2000

Muhammad Nuh, Penyebab Gagalnya Dakwah, GIP, Jakarta, 2000

Rayudaswati Budi, Pengantar Ilmu Komunikasi, Kretakupa, Makasar, 2010

Ridwan, Konseling dan Terapi Qur'ani, Pustaka Pelajar, Yogyakarta, 2018

Rosady Ruslan, Manajemen Public Relation dan Media Komunikasi, Jakarta, RajawaliPers, 2008

Steven W.L dan Karen A.F, Teori Komunikasi, Salemba Humanika, Jakarta, 2011

Yasien Muhammad, Insan Yang Suci, Mizan, Bandung, 1997

Thomas Lickona, Educating for Character, Bumi Aksara, 2016, Jakarta, hlm. 528-529

\section{$\underline{\text { Media On-line }}$}

https://www.liputan6.com/disabilitas/read/4523607/picu-gangguan-mentalalkohol-disebut-sebagai-akar-kecanduan-judi-dan-bunuh-diri

http://kompasiana.com, 17 Juni 2015

http://ejournal3.undip.ac.id/index.php/jkm

https://www.balitbangham.go.id/detailpost/maraknya-budaya-seks-bebas-diera-globalisasi-suatu-refleksi-moral 
journal.stainkudus.ac.id/index.php/RiwayahDOI: $\quad$-Volume 2 Nomor 2016ISSN: 2460-755Xe-ISSN: 2502-8839Urgensi Wudhu dan Relevansinya Bagi Kesehatan (Kajian Ma'anil Hadits) dalam Perspektif Imam Musbikin

https://cnnindonesia.com, selasa 10/09/2019 pada jam 05:40

Berita Satu, Kamis, 11 Desember 2014 | 20:07 WIB

Kontan.co.id, Senin, 01 Maret 2021 / 20:12 WIB

https://m.liputan6.com, 10 mei 2019, 21.00 wib 